\title{
Case Service System at the Child Welfare Institution using the Case-Based Reasoning Method
}

\author{
Citra Andriani \\ Department of Informatics \\ Engineering, Faculty of Engineering \\ Widyagama University \\ Malang, Indonesia
}

\author{
Gigih Priyandoko* \\ Department of Electrical \\ Engineering, Faculty of \\ Engineering \\ Widyagama University
}

Malang, Indonesia

\author{
Istiadi \\ Department of Informatics \\ Engineering, Faculty of \\ Engineering \\ Widyagama University \\ Malang, Indonesia
}

\author{
Mohd Helmy Abd Wahab \\ Department of Electrical Power \\ Engineering, Faculty of Electrical \\ and Electronic Engineering \\ Universiti Tun Hussein Onn \\ Malaysia, Parit Raja, Batu Pahat, \\ 86400 Johor, Malaysia
}

*Corresponding author: Gigih Priyandoko,gigih@widyagama.ac.id

\begin{abstract}
The Child Social Welfare Institution (LKSA) is an institution tasked with providing relief services to meet the standards of living, health, education, and the social needs of both individuals and groups. An LKSA Robbani is one of the institutions that help in handling family and child cases by National Standards for Child Care. In solving child problems, the institution must open the previous case data to determine the appropriate solution, such that the service process becomes long. Therefore, an application software is needed that can help the institution to be faster. The developed system is using the Case-Based Reasoning (CBR) Method. The advantage of this method is how to adapt the solutions of the previous case, as well as in seeking similarity in each case that the most significant similarity value is considered the most similar case. The method is very suitable for building the application. The system that was built had to do a trial before being used by the user. The trial result was carried out of the system with manual calculations using the case-based reasoning method. Furthermore, from the results of the trial, it was produced by $87.5 \%$.
\end{abstract}

Keywords - child welfare institution, case service system, Case-Based Reasoning

\section{INTRODUCTION}

The Child Social Welfare Institution (LKSA) is an institution tasked with providing relief services to meet the standards of living, health, education, and the social needs of both individuals and groups. LKSA is also the last alternative for abandoned children, no parents, and others. Not only that, LKSA is also a handling institution for every child and family problem. Based on the Republic of Indonesia Government Regulation No. 39 of 2012 article 1 [1], which states that the Implementation of Social Welfare is a directed, integrated and sustainable effort carried out by the Government, regional government and society in the form of social services to meet the basic needs of every citizen, includes social rehabilitation, social security, social empowerment, and social protection. The children's problems, it is categorized into several categories, one of which is child problems related to law $(\mathrm{ABH})$. Condition for underage children who have committed criminal acts such as stealing and so on. The child categorized as $\mathrm{ABH}$ must immediately receive service so as not to damage his future. An institution that assists the family is one of the improvement efforts, which is one of the LKSA that has recovery, protection, development, and improvement.

An LKSA Robbani is one of the institutions that help in handling family and child cases under SNPA (National Standards for Child Care). In solving child problems, the institution must open the previous case data to determine the appropriate solution, so that the service process becomes long. Therefore, an application is needed that can help the institution to be faster.

In LKSA, there are case data stored in separate folders when facing new cases. The institution must open the old case data to find a solution to the problem based on the new case. In solving this problem, a suitable solution method is needed. The developed system is using the Case-Based Reasoning (CBR) Method. Because this method can group by similarities between new cases and old ones. The advantage of this method is how to adapt the solutions of the previous case, as well as in seeking similarity in each case that the most significant similarity value is considered the most similar case. So that makes it easier to provide solutions. So that makes it easier to provide solutions. This method is very suitable for building the application. This application uses the PHP programming language and MySQL database.

The objectives of this project are (i) contribution in determining case services for child problems appropriately and efficiently, (ii) Become a more effective service system, (iii) Facilitate public access to LKSA services and (iv) Helping to solve family and child problems.

\section{CASe-Based ReAsoning Method}

Case-Based Reasoning (CBR) is a method for solving new problems by finding solutions to old cases that are similar then using the old case solution to solve new problems [2]. CaseBased Reasoning performs the process of remembering the resolution of the previous problem. Then when there are new problems, Case-Based Reasoning compares the 
characteristics of new problems with problems that have been previously resolved [3], [4].

The processes involved in CBR can be represented by a schematic cycle as shown in Figure 1. CBR is typical as a cyclical process comprising the four R's [3], [5]:

a. RETRIEVE the most similar case(s)

b. REUSE the case(s) to attempt to solve the problem

c. REVISE the proposed solution if necessary

d. RETAIN the new solution as a part of a new case.

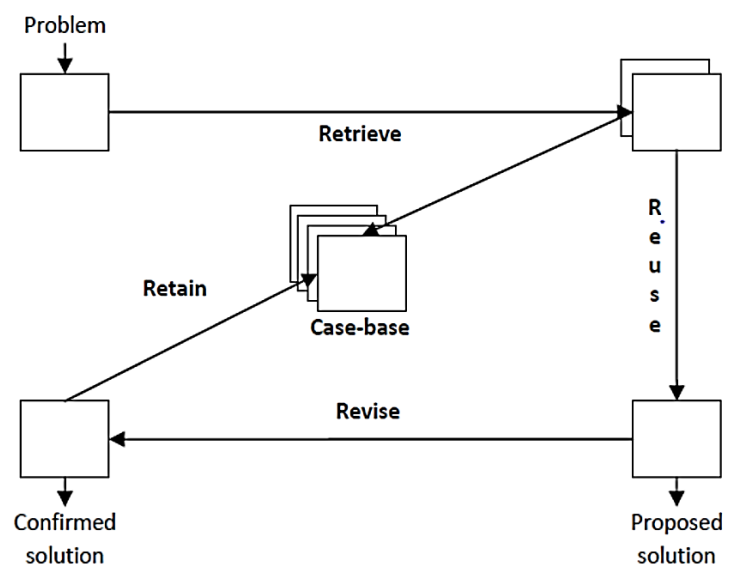

Fig. 1. The CBR Method Flow

Cases will be matched with cases in the CBR system, and one or more similar cases will be taken. Suggested solutions based on similar cases are then used and tested on new cases. Unless the case is suggested to be very suitable for the new case, then it is likely that revisions to the solution will be needed, and produce new cases to be retained/stored. The entire CBR process is carried out without human intervention or, in other words, automatically [4]. The advantages of using Case-Based Reasoning [6]:

a. We are reducing the task of acquiring knowledge.

b. Avoid repeating mistakes made in the past

c. Provide flexibility in modeling knowledge

d. Reasoning in a domain that is not yet fully understood, defined or modelled.

e. Make predictions of the possible success of the solutions offered.

f. Learning all the time

g. Reasoning in a domain with little knowledge.

h. Reasoning with incomplete or inappropriate data or concepts

i. Avoid repeating all steps that need to be taken to reach a solution

j. Provide an explanation tool

k. Expanding many different goals

1. Extending the reach of the domain

m. Reflect on human reasoning.

In the training phase, the algorithm only performs vector storage of feature vectors and classification of sample training data. In the classification phase, the same features are calculated for testing data (the classification is unknown). The new classification point is predicted to belong to the most classification of these points [5].

\section{PHP}

PHP is a server-side script programming language designed for web development. Also, PHP can be used as a general programming language. Initially, PHP stands for
Personal Home Page. As the name implies, PHP is used to create personal websites. The PHP was developed in 1995 by Rasmus Lerdorf and is managed by The PHP Group, now. The official PHP site is located at http://www.php.net. The PHP is called the server-side programming language because PHP is processed on a server computer. The PHP is a different programming language compared to client-side programming languages such as JavaScript which are processed on a web browser (client). Within a few years of development, PHP has become a powerful web programming language. It is not only used to create simple web pages, but also popular websites that are used by millions of people like Wikipedia, WordPress, Joomla. Currently, PHP stands for PHP: Hypertext Preprocessor, a recursive extension, which is a word game where the abbreviation consists of the abbreviation itself: PHP can be used free (free) and is Open Source. PHP released in the PHP License, slightly different from the GNU General Public License (GPL), which is commonly used for Open Source projects [6].

\section{RoBbani CHILD WELFARE INSTITUTION}

The concepts of childhood problems, conceptually, there are terms of children who need social protection (CNSP) or children who need special protection. There are a number of things that need to be considered, among others: First, if children in the relationship between children and those around them are not scheduled or deliberately left behind. Second, if the child is in an environment that experiences conflict or war. Third, if the child is employed well informally or formally, the child does not get attention or approval. Fourth, if the child does work that has a high risk such as construction, mining, drilling etc. Fifth, if the child uses psychoactive substances. Sixth, if children are discriminated against because fission disability from birth is also an accident. Seventh, if the social status of vulnerable children is discriminatory because of their marital status. Eighth, if the child corrects conflict with the law and must correct it with law enforcement authorities.

To get service from the Robbani Child Welfare Institution (LKSA Robbani) in the form of assistance in handling child cases/problems/household education/counseling. The community must register so that they become assisted by the institution. After that, the community will be given documents to be filled out and surveyed by the institution. In the service of children, it is not uncommon for LKSA to require third parties, such as their immediate family, local village officials, or volunteers, to connect institutions with the community. Based on the analysis carried out, the institution needs an intermediary so that the community and institutions can communicate well. Moreover, accelerate the handling of cases experienced by the community, so that this project makes an application that can support the performance of the institution.

\section{RESUlTS AND DisCUSSION}

The category table needs to develop and has contained categories of children and descriptions of explanations; the issues discussed are resolved based on the categories of children. Category Table can be seen in Table 1. While the Indicator data, as shown in Table 2 about the condition of the client. The system developed based on the client's problems based on the indicators and categories entered. After knowing the category and client indicators, the system provided 
solutions as a basis for the institution to resolve client problems. Alternative suggestions can be seen in Table 3, while the database of the case problem collected in Table 4.

TABLE I. CATEGORY TABLE

\begin{tabular}{|c|l|l|}
\hline Category_id & Category & \multicolumn{1}{c|}{ Description } \\
\hline 1 & $\begin{array}{l}\text { Displaced } \\
\text { Children }\end{array}$ & $\begin{array}{l}\text { Children who need special protection } \\
\text { because of the environment condition } \\
\text { that does not care }\end{array}$ \\
\hline 2 & $\begin{array}{l}\text { Street } \\
\text { Children }\end{array}$ & $\begin{array}{l}\text { Children who are employed either in } \\
\text { formal or informal ties and spend } \\
\text { more time on the streets, such as } \\
\text { being buskers, car dyers }\end{array}$ \\
\hline 3 & $\begin{array}{l}\text { Children } \\
\text { Face The } \\
\text { Law }\end{array}$ & $\begin{array}{l}\text { Underage children who commit } \\
\text { criminal acts and must deal with law } \\
\text { enforcement officers }\end{array}$ \\
\hline
\end{tabular}

TABLE II. INDICATORTABLE

\begin{tabular}{|c|l|c|}
\hline Indicator_id & \multicolumn{1}{|c|}{ Indicator } & Weight \\
\hline 1 & Orphans & 3 \\
\hline 2 & Lie Often & 3 \\
\hline 3 & Spend most of the time on the road & 2 \\
\hline 4 & Basic needs are not meet & 3 \\
\hline 5 & $\begin{array}{l}\text { Often steal in the family } \\
\text { environment }\end{array}$ & $\begin{array}{l}\text { Wandering in public places and } \\
\text { become traders, } \\
\text { windshield wipers, street singers }\end{array}$ \\
\hline 6 & Born because of rape & 3 \\
\hline 7 & Smokers & 3 \\
\hline 9 & Activities can endanger themselves & $\begin{array}{l}\text { Commit a crime robbery, } \\
\text { gambling, rape }\end{array}$ \\
\hline 10 & & 3 \\
\hline
\end{tabular}

TABLE III. SugGestion TABLE

\begin{tabular}{|c|l|}
\hline Sugestion_id & \multicolumn{1}{c|}{ Suggestion } \\
\hline 1 & Providing facilities to live in \\
\hline 2 & Providing proper education \\
\hline 3 & $\begin{array}{l}\text { Guidance Parenting Skill, Productive economic } \\
\text { business assistance, tracing and family } \\
\text { reunification }\end{array}$ \\
\hline 4 & $\begin{array}{l}\text { Introduction to the community, meetings with the } \\
\text { community leaders, program socialization }\end{array}$ \\
\hline 5 & $\begin{array}{l}\text { Bringing course, remedial course, skill training } \\
\text { Conduct social advocacy, legal advocacy, child } \\
\text { psychosocial assistance }\end{array}$ \\
\hline 6 &
\end{tabular}

TABLE IV. DATABASE TABLE

\begin{tabular}{|c|c|c|l|l|}
\hline Case_id & Category_id & Indicator_id & Category & $\begin{array}{l}\text { Indicat } \\
\text { or }\end{array}$ \\
\hline \multirow{2}{*}{1} & \multirow{2}{*}{1} & 1 & $\begin{array}{l}\text { Basic } \\
\text { needs } \\
\text { are not } \\
\text { meet }\end{array}$ \\
\cline { 3 - 4 } & & 7 & $\begin{array}{l}\text { Displaced } \\
\text { Children }\end{array}$ & $\begin{array}{l}\text { Born } \\
\text { because } \\
\text { of rape }\end{array}$ \\
\cline { 3 - 4 } & & 7 & & \\
\hline
\end{tabular}

\begin{tabular}{|c|c|c|c|c|}
\hline \multirow[b]{4}{*}{2} & \multirow[b]{4}{*}{1} & 1 & \multirow[b]{4}{*}{$\begin{array}{c}\text { Displaced } \\
\text { Children }\end{array}$} & Orphans \\
\hline & & 4 & & $\begin{array}{l}\text { Basic } \\
\text { needs } \\
\text { are not } \\
\text { meet }\end{array}$ \\
\hline & & 7 & & $\begin{array}{l}\text { Born } \\
\text { because } \\
\text { of rape }\end{array}$ \\
\hline & & 6 & & $\begin{array}{l}\text { Wander } \\
\text { ing in } \\
\text { public } \\
\text { places } \\
\text { and } \\
\text { become } \\
\text { traders, } \\
\text { windshi } \\
\text { eld } \\
\text { wipers, } \\
\text { street } \\
\text { singers }\end{array}$ \\
\hline \multirow{4}{*}{3} & \multirow{4}{*}{1} & 1 & \multirow{4}{*}{$\begin{array}{l}\text { Displaced } \\
\text { Children }\end{array}$} & Orphans \\
\hline & & 4 & & $\begin{array}{l}\text { Basic } \\
\text { needs } \\
\text { are not } \\
\text { met }\end{array}$ \\
\hline & & 7 & & $\begin{array}{l}\text { Born } \\
\text { because } \\
\text { of rape }\end{array}$ \\
\hline & & 3 & & $\begin{array}{l}\text { Spend } \\
\text { most of } \\
\text { the time } \\
\text { on the } \\
\text { road }\end{array}$ \\
\hline \multirow{4}{*}{4} & \multirow{4}{*}{2} & 1 & \multirow{4}{*}{$\begin{array}{l}\text { Street } \\
\text { Children }\end{array}$} & Orphans \\
\hline & & 3 & & $\begin{array}{l}\text { Spend } \\
\text { most of } \\
\text { the time } \\
\text { on the } \\
\text { road }\end{array}$ \\
\hline & & 6 & & $\begin{array}{l}\text { Wander } \\
\text { ing in } \\
\text { public } \\
\text { places } \\
\text { and } \\
\text { become } \\
\text { traders, } \\
\text { windshi } \\
\text { eld } \\
\text { wipers, } \\
\text { street } \\
\text { singers }\end{array}$ \\
\hline & & 9 & & $\begin{array}{l}\text { Activiti } \\
\text { es can } \\
\text { endange } \\
\mathrm{r} \\
\text { themsel } \\
\text { ves }\end{array}$ \\
\hline \multirow{4}{*}{5} & \multirow{4}{*}{2} & 1 & \multirow{4}{*}{$\begin{array}{l}\text { Street } \\
\text { Children }\end{array}$} & Orphans \\
\hline & & 4 & & $\begin{array}{l}\text { Basic } \\
\text { needs } \\
\text { are not } \\
\text { meet }\end{array}$ \\
\hline & & 3 & & $\begin{array}{l}\text { Spend } \\
\text { most of } \\
\text { the time } \\
\text { on the } \\
\text { road }\end{array}$ \\
\hline & & 6 & & $\begin{array}{l}\text { Wander } \\
\text { ing in } \\
\text { public }\end{array}$ \\
\hline
\end{tabular}




\begin{tabular}{|c|c|c|c|c|}
\hline & & & & $\begin{array}{l}\text { places } \\
\text { and } \\
\text { become } \\
\text { traders, } \\
\text { windshi } \\
\text { eld } \\
\text { wipers, } \\
\text { street } \\
\text { singers }\end{array}$ \\
\hline & & 9 & & $\begin{array}{l}\text { Activiti } \\
\text { es can } \\
\text { endange } \\
\mathrm{r} \\
\text { themsel } \\
\text { ves }\end{array}$ \\
\hline \multirow{5}{*}{6} & \multirow{5}{*}{3} & 1 & \multirow{5}{*}{$\begin{array}{l}\text { Children } \\
\text { Face The } \\
\text { Law }\end{array}$} & Orphans \\
\hline & & 4 & & $\begin{array}{l}\text { Basic } \\
\text { needs } \\
\text { are not } \\
\text { meet }\end{array}$ \\
\hline & & 8 & & $\begin{array}{l}\text { Smoker } \\
\mathrm{s}\end{array}$ \\
\hline & & 9 & & $\begin{array}{l}\text { Activiti } \\
\text { es can } \\
\text { endange } \\
\mathrm{r} \\
\text { themsel } \\
\text { ves }\end{array}$ \\
\hline & & 10 & & $\begin{array}{l}\text { Commit } \\
\text { a crime } \\
\text { robbery, } \\
\text { gamblin } \\
\text { g, rape }\end{array}$ \\
\hline \multirow{6}{*}{7} & \multirow{6}{*}{3} & 2 & \multirow{6}{*}{$\begin{array}{l}\text { Children } \\
\text { Face The } \\
\text { Law }\end{array}$} & $\begin{array}{l}\text { Lie } \\
\text { often }\end{array}$ \\
\hline & & 4 & & $\begin{array}{l}\text { Basic } \\
\text { needs } \\
\text { are not } \\
\text { meet }\end{array}$ \\
\hline & & 5 & & $\begin{array}{l}\text { Often } \\
\text { steal in } \\
\text { the } \\
\text { family }\end{array}$ \\
\hline & & 3 & & $\begin{array}{l}\text { Spend } \\
\text { most of } \\
\text { the time } \\
\text { on the } \\
\text { road }\end{array}$ \\
\hline & & 9 & & $\begin{array}{l}\text { Activiti } \\
\text { es can } \\
\text { endange } \\
\mathrm{r} \\
\text { themsel } \\
\text { ves } \\
\end{array}$ \\
\hline & & 8 & & Smoker \\
\hline
\end{tabular}

In order to implement the application software cases based on the tables above, the First step, the login page, as shown in Figure 2 is created and has contained a username and password. If the user did not have an account, the user needs to register first. The main page that includes the menu and refers to other menus, on the left side, the list and the top right corner displays the user's main page view according to the below. Admin and social workers only can access admin pages. Pages to entry a client problem are provided. They are the indicator input page display, indicator data, and so on shown in Figures 4-9.

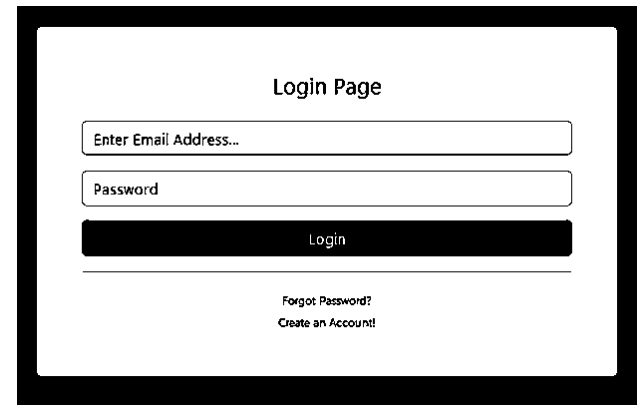

Fig. 2. The System Page Login

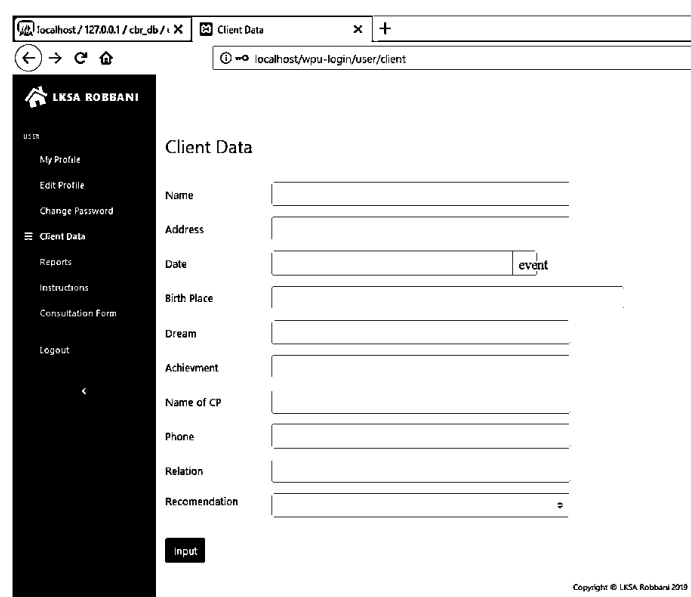

Fig. 3. The System Input Client Page

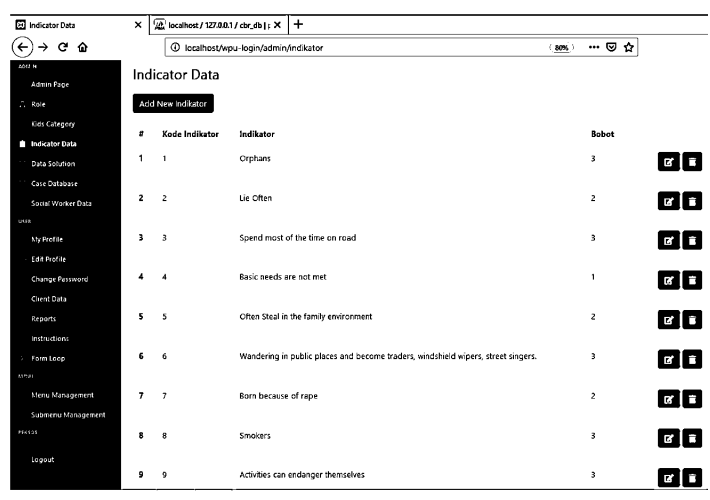

Fig. 4. The Indicator Data

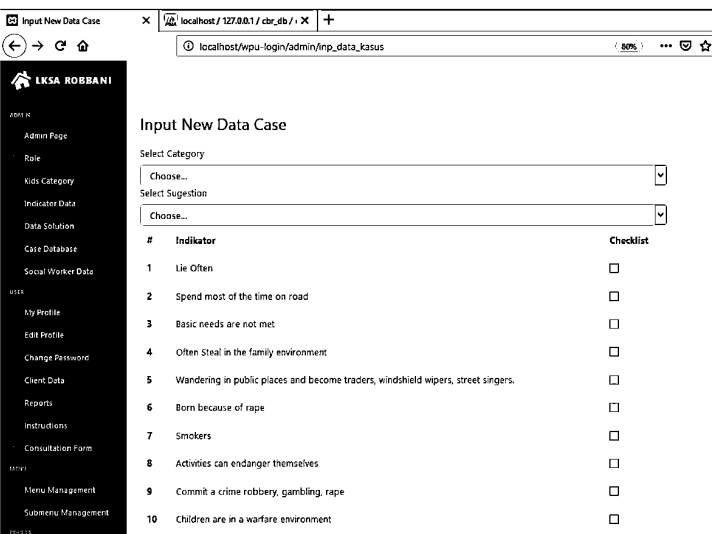

Fig. 5. The New Input Client Data 


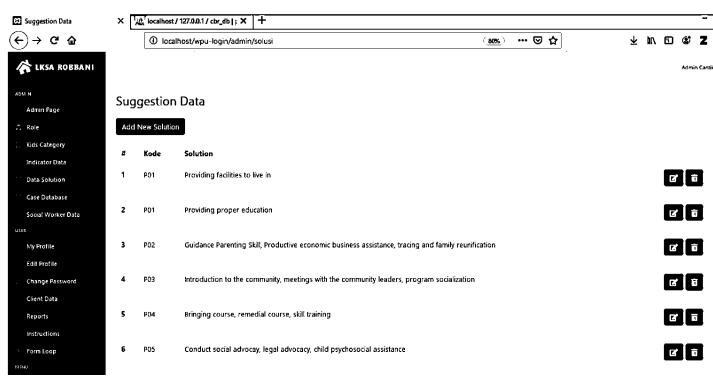

Fig. 6. The Suggestion Data

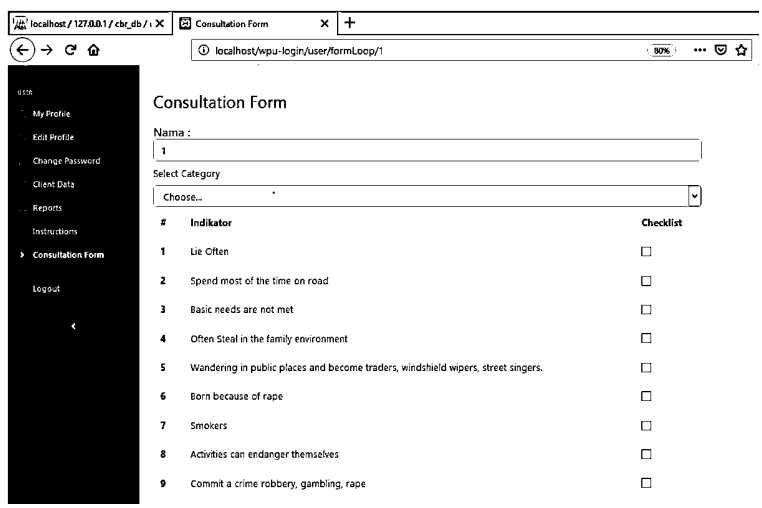

Fig. 7. The Consultation Form

The testing phase is to calculate the results of the system and be calculated with manual calculations. The first step is to select clients who will be reported to get service then select the category and indicator that matches the client's condition, click the consult button to get the results. The suggestion will be shown and can be printed by Admin. The admin will print the results and will convey to the client how to address the problem.

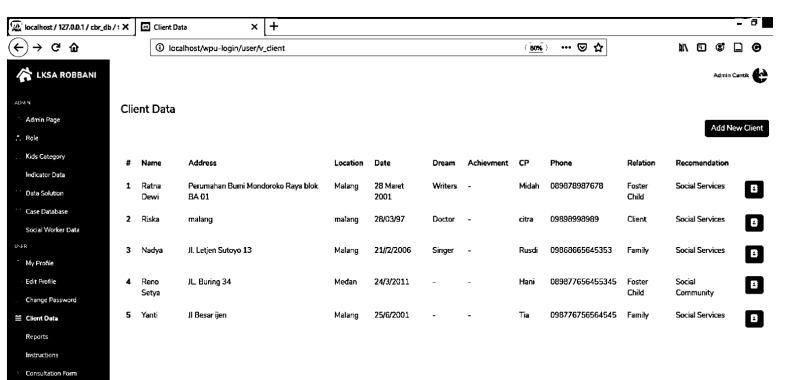

Fig. 8. The Client Data

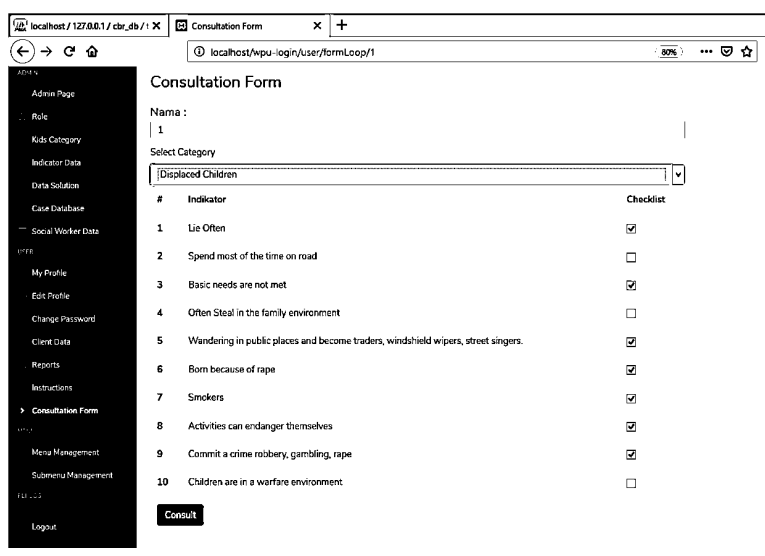

Fig. 9. The Consultation Form
The system built must be tested before being used by real users. The technology used in building the system has been developed, the system interface used, which consists of data used in the application of indicator data, category data, case data has been created. After some experiments have been carried out, using the CBR method obtained 87.5\%.

\section{CONCLUSION}

The purpose of this study is to facilitate institutions in providing services to troubled clients or children, a case service system based on a case-based reasoning method that is built into a solution to the problems faced by the institution. By inputting several indicators based on the client's conditions and categories, then a solution will be obtained for the client. And there is a percentage of similarities between the old case and the new case to facilitate the institution, so the institution does not need to open the old case document, which can slow down the service of the case. Case service systems based on the case-based reasoning method can be implemented in institutions, and trials have been carried out with a percentage similarity result of $87.5 \%$. Even though this system gets good results, the institution can only read the results of the consultation because it does not issue information from the selected indicator. This system can also be applied by combining several methods so that the results obtained are more accurate.

\section{ACKNOWLEDGEMENT}

The authors would like to thank the Widyagama University, Indonesia research fund for supporting this research.

\section{REFERENCES}

[1] UU-11, KesejahteraanSosial, 2009.

[2] Salamun, "Penerapan Algoritma Nearest Neighbour dan CBR pada Expert System Penyimpangan Perilaku Seksual", JOIN J. Online Inform., vol. 2, no. 2, pp. 63-70, Desember 2017.

[3] L. Verma, S. Srinivasan, and V. Sapra, "Integration of Rule-based and Case-Based Reasoning System to Support Decision Making", IEEE, p. 3, 2014.

[4] E. T. Luthfi, "Penerapan Case Based Reasoning Dalam Mendukung Penyelesaian Kasus", STMIK AMIKOM Yogyakarta, 2017.

[5] I. Purwandani, "Penerapan Case Based Reasoning Dan Nearest Neighbour Retrieval Untuk Diagnosa Penyakit Langganan Anak", J. Speed Sentra Penelit. Eng. Dan Edukasi, vol. 9, no. 2, pp. 1-7, 2017.

[6] Pengertian dan Fungsi PHP dalam Pemrograman Web Duniailkom. [Online]. Available: https://www.duniailkom.com/pengertian-danfungsi-phpdalam-pemograman-web/ [Accessed: 16-Jun-2019].

[7] Profil Lembaga Kesejahteraan Sosial Robbani, LKSA ROBBANI, 2010.

[8] Studi Kasus / Problem Solving. Lembaga Kesejahteraan Sosial Anak Robbani, 01-Sep-2014.

[9] Y. A. Gerhana, H. . Sudanyana, and T. Budiman, "Case Based Reasoning (CBR) dan Pengembangan Kemampuan Penyelesaian Masalah", UIN Sunan Gunung Djati Bdg., vol. 2, p. 16, Jul. 2013.

[10] R. Hardianto, "Sistem Pakar Penentuan Tipe Kepribadian Siswa Sekolah Dasar Menggunakan Metode Case Base Reasoning”, J. Inf. Technol. Comput. Sci. INTECOMS, vol. 1, no. 2 Desember 2018, p. $11,2015$.

[11] M. Shaid, W. L. YS, and Y. R. Utami, "Sistem Pakar Pertumbuhan Balita Berbasis Web Dengan Metode case Base Reasoning", J. TIKomSiN, p. 8. 2017. 
[12] A. A. Fahmi, "Rancang Bangun Aplikasi Untuk Pemecahan Masalah Mahasiswa Menggunakan Metode Case Based Reasoning Dengan Pendekatan Psikologi Positif", Universitas Islam Negeri Maulana Malik Ibrahim, Malang, 2014.

[13] S. Hendra and S. Kusumadewi, "Perancangan Aplikasi Konseling Mahasiswa Menggunakan Metode Case Based Reasoning”, p. 8. 2016,

[14] U. Saripudin, Y. A. Gerhana, and C. Slamet, "Pengaruh Case-Base Reasoning (CBR) Terhadap Kemampuan Pemecahan Masalah Siswa
(Penerapan Pada Pembelajaran Bahasa Indonesia)", UIN Sunan Gunung Djati Bdg., vol. IX, p. 25. 2015.

[15] R. Retnowati and A. Pujiyanta, "Implementasi Case Base Reasoning Pada Sistem Pakar Dalam Menentukan Jenis Gangguan Kejiwaan”, J. Sarj. Tek. Inform., vol. 1, p. 10, Jun. 2013. 